\title{
Ornithine decarboxylase activity during development of the mouse inner ear in vivo and in vitro
}

\author{
Sherry A. Crann ${ }^{1}$, Thomas R. Van de Water ${ }^{2}$, and Jochen Schacht ${ }^{1}$ \\ ${ }^{1}$ Kresge Hearing Research Institute, University of Michigan, Ann Arbor, MI 48109-0506, USA \\ ${ }^{2}$ Department of Otolaryngology and Department of Neuroscience, Laboratory of Developmental Otobiology, Albert Einstein College \\ of Medicine, Bronx, NY 10461, USA
}

Accepted April 22, 1991

\begin{abstract}
Summary. Ornithine decarboxylase activity was determined during the development of the peripheral auditory system in the murine otocyst with the goal of understanding the role of this enzyme in the morphological and functional maturation of the inner ear. At gestational days 11 and 12 enzyme activity was more than 10-fold higher than adult levels. A sharp decline occured between day 12 and 13 after which activity rose to a peak around day 15 . Activity then dropped continuously until near-adult levels were reached at birth. A lower specific activity of ODC but a similar time-course was seen in otocysts explanted at gestational day 13 and subsequently cultured for 6 days. For two stages of development, enzyme activity and binding of ${ }^{3} \mathrm{H}$ - $\alpha$-difluoromethylornithine were compared. The four-fold difference in enzymatic activity on gestational days 15 and 17 was paralleled by a similar difference in binding. Ornithine decarboxylase activity during inner ear development therefore seems primarily regulated at the level of protein synthesis. Ornithine decarboxylase activity correlates with major inductive events in the morphogenesis of the cartilagenous otic capsule that serves as a template for the formation of the bony labyrinth. The pattern of activity may reflect the changes in the head mesenchyme that is recruited by the otocyst to aggregate and form its protective otic capsule.
\end{abstract}

Key words: Ornithine decarboxylase - Development, ontogenic - Otocysts - Ear, inner - Mesenchyme - Morphogenesis - Mouse (CBAxC57)

Ornithine decarboxylase (ODC; EC 4.1.1.17) catalyzes the conversion of ornithine to putrescine, the rate limiting step in polyamine synthesis. ODC activity is significantly higher in developing and regenerating tissues than in mature tissues, and the enzyme appears crucial to organ development and cellular repair in a number of systems (Fozard et al. 1980; Russell 1985). Polyamines

Offprint requests to : J. Schacht are important effectors of cellular mechanisms via DNA stabilization and synthesis (Hougaard and Larsson 1989; Slotkin et al. 1984), regulation of protein synthesis (Slotkin et al. 1984) and of enzymes unrelated to polyamine pathways (Gilad and Gilad 1984), membrane stabilization (Ballas et al. 1983), and augmentation of receptor actions (Koenig et al. 1983). ODC activity is regulated by mechanisms which include feedback inhibition by polyamines (Pegg 1986), a protein inhibitor "antizyme" (Fong et al. 1976), phosphorylation (Atmar and Kuehn 1981), and induction by gene amplification and increased rate of translation (Hougaard and Larsson. 1989). This high degree of regulation suggests a critical role for ODC and polyamines in cellular function. ODC is ubiquitous and we have previously shown it to be present in tissues of the inner ear (Henley et al. 1987).

Hearing loss has been reported in patients receiving the antitumor agent $\alpha$-difluoromethylornithine (DFMO), a specific inhibitor of ODC (Sjoerdsma and Schechter 1984), and DFMO-induced hearing loss has been confirmed in the guinea pig (Jansen et al. 1989). Postnatal changes of ODC and a critical period for DFMO ototoxicity have been observed in the developing pigmented rat (Henley et al. 1990). However, a role of ODC in the development and function of the inner ear has not been established yet. This study was designed to investigate ODC activity during the prenatal development of the peripheral auditory system of the mouse with the goal of understanding the role of this enzyme in the morphological and functional maturation of the inner ear. The murine otocyst was chosen as the developmental model because of the major morphogenetic changes it undergoes during embryonic development (Van De Water 1984).

\section{Materials and methods}

\section{Tissue preparation}

CBA males were bred with C57B16 females to yield CBA/C57B16 hybrid embryos. Timed pregnancies were obtained by the vaginal 
plug method with the day of plug occurrence designated gestational day (gd) one. Actual embryonic age was determined by somite count until gd 13, thereafter by a combination of somite count and external features (Theiler 1972).

Otocysts were excised from embryos of gd 11 through 18. Gravid mice were killed by cervical dislocation and the embryos removed and placed in Dulbecco's phosphate buffered saline $(\mathrm{pH}$ 7.4) kept at $4^{\circ}$. The otocyst, surrounding periotic mesenchyme, and cochlear-vestibular ganglion complex (CVG) were excised from embryos of gd 11 through 13 . The otic capsule is a defined entity by gd 14, and from this time on the cartilaginous capsule, membranous labyrinth and the CVG complex were extirpated as a unit. Each specimen was placed into an individual test tube, quick-frozen in liquid nitrogen and stored at $-70^{\circ} \mathrm{C}$.

For otocyst cultures, explants from embryos of gd 13 were maintained in $35 \mathrm{~mm}$ plastic dishes containing $1 \mathrm{ml}$ of Newman \& Tytell Serumless Medium supplemented with $10 \%$ heat-inactivated fetal calf serum. Six samples were cultured per dish and medium was completely exchanged every 48 hours. The culture chamber was kept at $37^{\circ}$, saturated humidity and a gas composition of $5 \% \mathrm{CO}_{2}$ in room air. Upon termination of culture, the specimens were briefly washed in PBS, quick-frozen and stored at $-70^{\circ} \mathrm{C}$ as described for the in vivo specimens.

\section{$O D C$ assays}

Single otocysts were homogenized by hand in a $200 \mu \mathrm{l}$ glass/glass homogenizer in $60 \mu \mathrm{l}$ of $125 \mathrm{mM} \mathrm{N}$-[2-hydroxyethyl] piperazine$\mathrm{N}^{\prime}$-[2-ethanesulfonic acid] (HEPES), pH 7.2, $5 \mathrm{mM}$ dithioerythritol (DTE), $0.25 \mathrm{mM}$ ethylenediamine tetraacetate (EDTA), $125 \mu \mathrm{M}$ pyridoxal 5-phosphate (PLP), and $10 \mu \mathrm{M}$ phenylmethylsulfonyl fluoride. The homogenate was centrifuged at $12500 \mathrm{~g}$ for $15 \mathrm{~min}$. An aliquot of the resulting supernatant was assayed for protein (Bradford 1976). Another aliquot was combined with half as much volume of $2 \mathrm{mg}$ bovine serum albumin/ml (to stabilize protein) and assayed for enzyme activity. All manipulations prior to the enzyme assay were done at $4^{\circ} \mathrm{C}$.

ODC was assayed by a modification of the procedure of Russell and Snyder (1968) as previously described (Henley et al. 1987). The supernatant fraction (1 to $12 \mu \mathrm{g}$ of protein) was incubated at $37^{\circ}$ for $60 \mathrm{~min}$ in closed incubation vessels in a total volume of $50 \mu \mathrm{l}$ of (final concentrations) $50 \mathrm{mM}$ HEPES, pH 7.2, $2 \mathrm{mM}$ DTE, $0.1 \mathrm{mM}$ EDTA, $0.2 \mathrm{mg} \mathrm{BSA} / \mu \mathrm{l}, 50 \mu \mathrm{M}$ PLP, and $300 \mu \mathrm{M}$ L-ornithine or DL-ornithine $\left(\mathrm{L}-\left[1-{ }^{14} \mathrm{C}\right]\right.$ ornithine, $52.3 \mathrm{mCi}$ / mmole; DL- $\left[1-{ }^{14} \mathrm{C}\right]$ ornithine, $50.3 \mathrm{mCi} /$ mmole; New England $\mathrm{Nu}-$ clear, Wilmington, Del., USA). Five hundred $\mu \mathrm{M}$ of $\alpha$-difluoromethyl-ornithine (DFMO; a gift from the Merrell Dow Research Institute, Cincinnati, Ohio, USA) was added to parallel incubations as a specific inhibitor of ODC. Incubations were terminated by the injection of $200 \mu \mathrm{l}$ of $4 \mathrm{~N} \mathrm{H}_{2} \mathrm{SO}_{4}$ into the vessels and postincubated for at least $45 \mathrm{~min}$ at room temperature to trap the evolving $\mathrm{CO}_{2}$ on to filters previously wetted with $40 \% \mathrm{KOH}$. The filters were then removed from the reaction vials, the $\mathrm{KOH}$ was neutralized with acetic acid, and radioactivity determined by liquid scintillation counting. Duplicates were run of each condition and $\mathrm{ODC}$ activity was determined as that fraction of total $\mathrm{CO}_{2}$ produced $/ \mathrm{hr} / \mathrm{mg}$ protein that was inhibited by DFMO.

Binding studies with tritiated DFMO were performed under conditions similar to that of the ODC activity assay. Three to four otocysts were homogenized in $165 \mu$ l of buffer and centrifuged as above. An aliquot of the supernatant was assayed for protein, another for ODC activity, and a third was used for the binding assay. For the binding assay, the supernatant was combined with DL- $\alpha-\left[3,4-{ }^{3} \mathrm{H}\right]-\mathrm{DFMO}$ (26.6 Ci/mmol; New England Nuclear, Wilmington, Del., USA) at a final concentration of $1.4 \mu \mathrm{M}$. The sample was incubated for $60 \mathrm{~min}$ at $37^{\circ}$, removed to ice for approximately $5 \mathrm{~min}$ and then applied, at room temperature, to a column $(4 \mathrm{~mm} \times 25 \mathrm{~cm})$ of Sephadex G-25-50 previously equilibrated with the assay buffer. Fractions of approximately $100 \mu \mathrm{l}$ were collected, the protein-containing fractions were pooled and aliquots for total

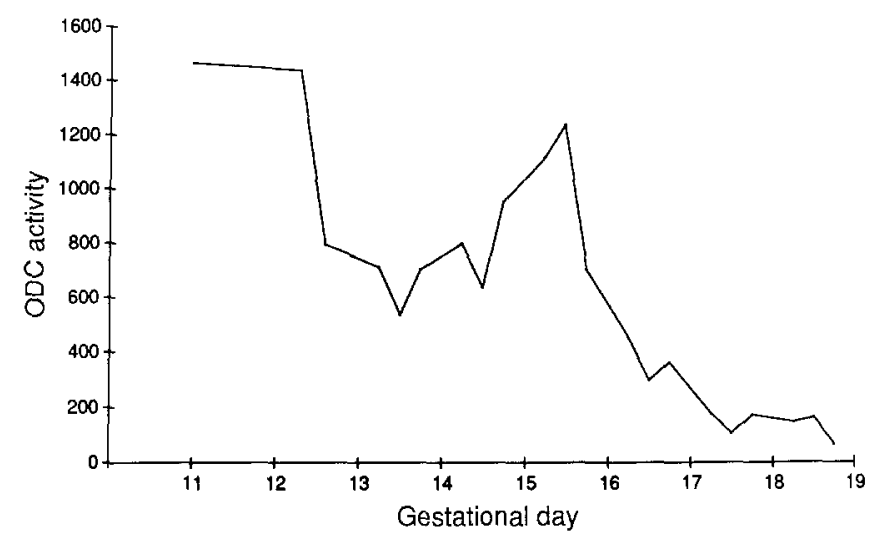

Fig. 1. $O D C$ activity as a function of developmental stage. From each gestational day, three otocysts were assayed for ODC activity as described in "Materials and methods". ODC activity is expressed as pmoles $\mathrm{CO}_{2}$ formed $\times \mathrm{mg}^{-1}$ protein $\times \mathrm{h}^{-1}$ and values are means from duplicate analyses of individual otocyst. Otocysts were ranked by protein content within a given gestational day as discussed in "Results"

protein and radioactivity were taken. A second aliquot from the same supernatant was assayed for ${ }^{3} \mathrm{H}$-DFMO binding after preincubation at $37^{\circ}$ for 30 minutes with $500 \mu \mathrm{M}$ unlabelled DFMO to correct for nonspecific binding.

\section{Results}

Three aspects of ODC activity were investigated: (1) the time course of ODC activity of the developing inner ear; (2) the correlation of ${ }^{3} \mathrm{H}-\mathrm{DFMO}$ binding with ODC enzymatic activity; (3) the time course of ODC activity in otocysts explanted at gd 13 and cultured in vitro.

\section{$O D C$ activity during development in vivo}

The activity of ODC in otocysts changed significantly during development of the inner ear (Fig. 1). The ODC activity was expressed as enzymatic activity per mg protein to correct for changes due to increase in total otocyst mass. In addition, individual otocysts were ranked by protein content or weight to control for the possibility that otocysts from a given "gestational day" included specimens of slightly different development stages. Such a ranking should more accurately reflect subtle and discrete changes during development. However, comparison of the data revealed that the changes in ODC activity were evident regardless of the normalization procedure.

For comparison of ODC in the developing otocyst with that in the mature cochlea, the enzyme was analyzed in cochlear tissues of mature 44-day old mice. ODC activity was found to be $134 \pm 23$ pmoles $\mathrm{CO}_{2}$ formed $/ \mathrm{mg}$ protein $/ \mathrm{h}$. In contrast, activity in the developing ototcyst (gd 11 and 12) was more than 10-fold higher. A sharp decline in ODC activity occured between day 12 and 13 after which activity rose to a peak around gd 15 (significance of difference between day 13 and 15: $0.05<P<0.1$ ). At this stage, activity dropped continuously until near-adult levels were reached at birth. 
Table 1. DFMO binding and ODC activity. DFMO binding and ODC activity were assayed on the same otocysts as described in "Materials and methods". Numbers are means \pm SD from three specimens for each gestational day

\begin{tabular}{llll}
$\begin{array}{l}\text { Develop- } \\
\text { mental } \\
\text { stage }\end{array}$ & $\begin{array}{l}\text { DFMO binding } \\
\text { (dpm/mg } \\
\text { protein) }\end{array}$ & $\begin{array}{l}\text { ODC activity } \\
\text { (pmoles CO } \\
\text { formed } / \mathrm{h} / \mathrm{mg} \\
\text { protein) }\end{array}$ & Ratio $^{\mathrm{a}}$ \\
\hline Gd 15 & $36100 \pm 5800$ & $1508 \pm 149$ & 24 \\
Gd 17 & $8500 \pm 6000$ & $423 \pm 26$ & 20 \\
\hline
\end{tabular}

a DFMO bound per unit of ODC activity

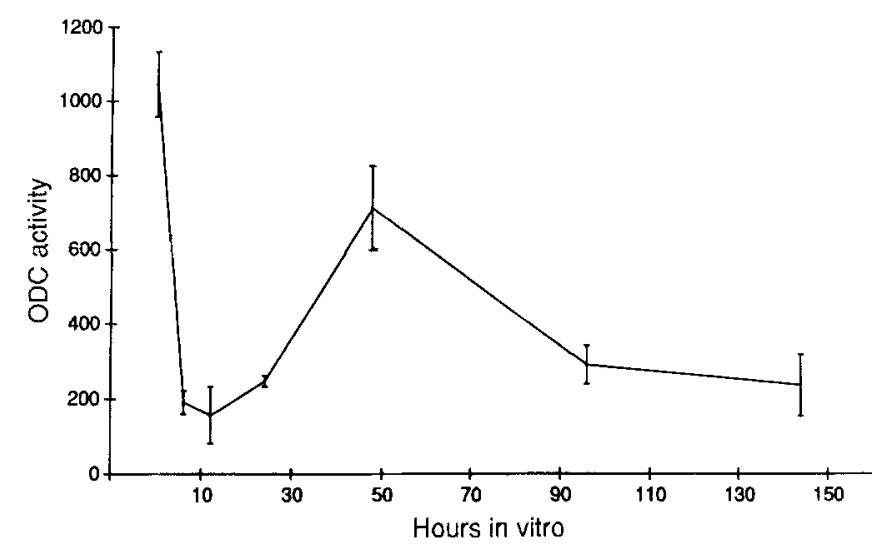

Fig. 2. $O D C$ activity in otocysts in vitro. Otocysts were explanted at gd 13 and specific activity of ODC was assayed as described in "Materials and methods". ODC activity is expressed as pmoles $\mathrm{CO}_{2}$ formed $\times \mathrm{mg}^{-1}$ protein $\times \mathrm{h}^{-1}$ and values are means $\pm \mathrm{SD}$ of triplicate determinations

\section{Binding of radiolabelled DFMO}

For two stages of development, aliquots of the enzyme fractions were assayed for binding of ${ }^{3} \mathrm{H}-\mathrm{DFMO}$ and ODC activity. Gestational days 15 and 17 were selected as they corresponded to a peak and a trough in enzymatic activity. The approximately four-fold difference in ODC activity was paralleled by a similar difference in the specific binding of ${ }^{3} \mathrm{H}-\mathrm{DFMO}$ (Table 1 ).

\section{$O D C$ activity during development in vitro}

The third aspect of this study addressed the question whether the in vitro system reflected the pattern of ODC activity in vivo. Otocysts were explanted at gd 13 and cultured for 6 days $(144 \mathrm{~h})$. The specific activity of ODC dropped rapidly after the otocyst was explanted (Fig. 2) and rose to a peak after $48 \mathrm{~h}$ (significance, $P<0.01$ ). This time corresponds to the second division in vitro. At $144 \mathrm{~h}$ in vitro, ODC values were similar to those in otocysts in vivo at day 18 to 19 .

\section{Discussion}

The time course of ODC activity shows a clear and distinct pattern of peaks and troughs during development of the inner ear. Although more prominently displayed in vivo, activity changes are also present in the organ culture of the otocyst. The major questions arising from this first study of ODC in the developing inner ear are: (1) what mechanism(s) determine the time course of enzymatic activity and (2) what aspects of development are controlled by ODC.

Two mechanisms may account for the peaks and troughs in ODC activity during development: (1) changes in the amount of enzyme (due to induction of its synthesis); (2) variations in the activity of the enzyme due to inhibition by regulators such as a specific antizyme. The enzyme assay based on decarboxylation of ornithine determines the activity of ODC, whereas binding of the specific inhibitor DFMO reflects the amount of ODC protein present. Thus, as the binding of DFMO parallels the peak and trough seen in the enzyme assays, the variation in ODC activity appears to be based upon varying concentrations of the enzyme. ODC activity during inner ear development therefore seems primarily regulated at the level of protein synthesis.

The second question is more difficult to address and will require further detailed studies. During the period studied, tissue interactions modulate the developmental rates of both the epithelial and mesenchymal tissues that eventually form the membranous and bony labyrinths (McPhee and Van de Water 1986). There are also major shifts in the synthesis of matrix molecules that are involved in the formation of the cartilagenous otic capsule and the perilymphatic spaces (D'Amico-Martel et al. 1987; McPhee and Van De Water 1985). A few correlations appear obvious. High ODC levels on day 11 correspond to high levels of cellular proliferation in the surrounding periotic mesenchyme which occurs just prior to the aggregation phase of otic capsule development between the 11 th and 12 th $\mathrm{gd}$. On the 12 th gd, during which ODC levels are still elevated, periotic mesenchyme is aggregated and an extracellular matrix is actively being produced by the prechondrogenic mesenchyme (McPhee and Van De Water 1985; 1986). During gd 13 a large subset of cells of the aggregated periotic mesenchyme are involved in the formation of the perilymphatic spaces (McPhee et al. 1987). This coincides with the decrease in ODC activity. Between days 14 and 16 of gestation a mature cartilaginous capsule is produced coinciding with the peaks of ODC activity between gestation days 14 and 15.

The ODC inhibitor DFMO in combination with the in vitro system should provide a valuable tool in the further elucidation of possible connections between ODC activity and specific features of otocyst morphogenesis. Otocysts undergo morphogenesis in culture as they do in vivo, although some specific features such as tight junctions may not reach the same degree of maturity (Berggren et al. 1987). ODC levels in vitro reflect the changes of enzyme activity in vivo. The precipitous drop of enzyme activity after explantation at gd 13 is consistent with observations in other explanted organ systems (Huber and Brown 1982). Division 2 which corresponds to gd 15 in the in vivo development shows a clear peak of activity albeit of lower absolute activity 
than in vivo. If the application of DFMO leads to dysmorphogenesis at specific stages of development, correlations may be drawn between inhibition of ODC activity and the disruption of normal morphogenetic expression. A similar experimental approach using a proline antagonist was successful in studying the role of proline synthesis during development of otic explants (Van De Water and Galinovic-Schwartz 1986).

In conclusion, ODC activity appears to correlate with major inductive events in the morphogenesis and formation of the cartilagenous otic capsule that serves as a template for the formation of the bony labyrinth. ODC activity may reflect the changes in the head mesenchyme that is recruited by the otocyst to aggregate and form its protective otic capsule.

Acknowledgements. This work was supported by a grant from the Deafness Research Foundation (J.S.) and NIH Grant DC-00088 (T.R.VDW.).

\section{References}

Atmar VJ, Kuehn GD (1981) Phosphorylation of ornithine decarboxylase by a polyamine-dependent protein kinase. Proc Natl Acad Sci USA 78:5518-5522

Ballas SK, Mohandas N, Marton LJ, Shohet SB (1983) Stabilization of erythrocyte membranes by polyamines. Proc Natl Acad Sci USA 80:1942-1946

Berger FG, Szymanski P, Read E, Watson G (1984) Androgenregulated ornithine decarboxylase mRNAs of mouse kidney. J Biol Chem 259:7941-7946

Berggren D, Bagger-Sjöbäck D, Anniko M (1987) Formation of junctional complexes in otocysts developed in vitro. A freezefracture study. Acta Otolaryngol 104:146-152

Bradford MM (1976) A rapid and sensitive method for the quantitation of microgram quantities of protein utilizing the principle of protein-dye binding. Anal Biochem 72:248-254

Canellakis ES, Kyriakidis DA, Heller JS, Palak JW (1981) The complexity of regulation of ornithine decarboxylase. Med Biol 59:279-285

D'Amico-Martel A, Van De Water TR, Wootton JAM, Minor RR (1987) Changes in the types of collagen synthesized during chondrogenesis of the mouse otic capsule. Dev Biol 120:542555

Fong WF, Heller JS, Canellakis ES (1976) The appearance of an ornithine decarboxylase inhibitory protein upon addition of putrescine to cell culture. Biochim Biophys Acta 428:456-465

Fozard JR, Part M, Prakash NJ, Grove J, Schechter PJ, Sjoerdsma A, Koch-Weser J (1980) L-Ornithine decarboxylase: an essential role in early mammalian embryogenesis. Science 208:505-508

Gilad GM, Gilad VH (1984) Reciprocal regulation of ornithine decarboxylase and choline kinase activities by their respective reaction products in the developing rat cerebellar cortex. J Neurochem 43:1538-1543

Henley CM, Gerhardt HJ, Schacht J (1987) Inhibition of inner ear ornithine decarboxylase by neomycin in vitro. Brain Res Bull 19:695-698

Henley CM, Atkins J, Martin G and Lonsbury-Martin B (1990) Critical period for $\alpha$-difluoromethylornithine in the developing pigmented rat. J Cell Biol [Suppl] 14F:22

Hougaard DM, Larsson L (1989) Polyamines, molecules necessary for cell division. Eur J Cell Biol 48:14-18

Huber BE, Brown NA (1982) Developmental patterns of ornithine decarboxylase activity in organogenesis phase rat embryos in culture and in utero. In Vitro 18:599-605

Jansen C, Mattox DE, Miller KD and Brownell WE (1989) An animal model of hearing loss from $\alpha$-difluoromethylornithine. Arch Otolaryngol Head Neck Surg 115:1234-1237

Koenig H, Goldstone A, Lu CY (1983) Polyamines regulate calcium fluxes in a rapid plasma membrane response. Nature $305: 530-534$

Kontula KK, Torkkeli TK, Bardin CW, Janne OA (1984) Androgen induction of ornithine decarboxylase mRNA in mouse kidney as studied by complementary DNA. Proc Natl Acad Sci USA $81: 731-735$

McPhee JR, Van De Water TR (1985) A comparison of morphological stages and sulfated glycosaminoglycan production during otic capsule formation: in vivo and in vitro. Anat $\operatorname{Rec} 213: 566$ 577

McPhee JR, Van De Water TR (1986) Epithelial-mesenchymal tissue interactions guiding otic capsule formation: the role of the otocyst. J Embryol Exp Morphol 97:1-24

McPhee JR, Van De Water TR, Su H (1987) Hyaluronate production by the inner ear during otic capsule and perilymphatic space formation. Am J Otolaryngol 8:265-272

Pegg AE (1986) Recent advances in the biochemistry of polyamines in eukaryotes. Biochem J 234:249-262

Russell DH (1985) Ornithine decarboxylase: A key regulatory enzyme in normal and neoplastic growth. Drug Metabolism Rev $16: 1-88$

Russell D, Snyder SH (1986) Amine synthesis in rapidly growing tissues: ornithine decarboxylase activity in regenerating rat liver, chick embryo, and various tumors. Proc Natl Acad Sci USA 60:1420-1427

Slotkin TA, Persons D, Slepetis RJ, Taylor D, Bartolome J (1984) Control of nucleic acid and protein synthesis in developing brain, kidney, and heart of the neonatal rat: effects of $\alpha$ difluoromethylornithine, a specific, irreversible inhibitor of ornithine decarboxylase. Teratology $30: 211-224$

Thieler K (1972) The house mouse. Springer, Berlin Heidelberg New York

Van De Water TR (1984) Developmental mechanisms of mammalian inner ear formation. In: Berlin $C$ (ed) Hearing science. College Hill Press, San Diego, pp 49-108

Van De Water TR, Galinovic-Schwartz V (1986) Dysmorphogenesis of the inner ear: disruption of extracellular matrix (ECM) formation by an L-proline analog in otic explants. J Craniofac Gen Dev Biol 6:113-129 